\title{
Perbandingan Potensi Daun Ketepeng dan Minyak Ikan Lemuru sebagai Agensia Reduksi Metan dalam Memperbaiki Kualitas Pakan Ternak Ruminansia
}

\author{
S. D. Widyawati \\ Program Studi Peternakan, Fakultas Pertanian, Universitas Sebelas Maret \\ Jl. Ir. Sutami 36A, Surakarta 57126
}

\begin{abstract}
ABSTRAK
Penelitian bertujuan untuk mengkaji potensi daun ketepeng dan minyak ikan lemuru sebagai agensia reduksi metan dalam pakan suplemen yang ditambahkan dalam pakan basal rumput lapangan. Komposisi pakan suplemen, daun lamtoro (DL), urea dan molases dalam rasio 1:5, 1:6 dan 1:7 serta daun ketepeng (DK) dan minyak ikan lemuru (MIL) sebagai agensia reduksi metan. Pakan suplemen yang ditambahkan dalam rumput lapangan berturut-turut P1 : U:M=1:5, DK, P2 : $\mathrm{U}: \mathrm{M}=1: 5, \mathrm{MIL}, \mathrm{P} 3$ : U:M=1:6, DK P4 : U:M=1:6, MIL, P5 : U:M=1:7, DK, P6 : U:M=1:7, MIL. Penelitian ini dikerjakan dengan teknik in vitro gas. Inokulum diambil cairan rumen sapi PO jantan berfistula, pengambilan cairan rumen dilakukan sebelum sapi diberi pakan pagi hari. Hasil penelitian menunjukkan bahwa derajat keasaman $(\mathrm{pH})$ cairan rumen berbeda tidak nyata, hal ini menunjukkan proses fermentasi mikrobial dalam rumen berjalan secara baik dan tidak dipengaruhi oleh perlakuan. Produksi VFA yang rendah dihasilkan pada perlakuan P5 dan P6, sedangkan P1, $\mathrm{P} 2$, P3 dan $\mathrm{P} 4$ nyata $(\mathrm{P}<0,05)$ lebih tinggi. Produksi asam asetat $(\mathrm{C} 2)$ sejalan dengan produksi VFA, dan asam propionat $(\mathrm{C} 3)$ relatif sama kecuali pada P6 nyata $(\mathrm{P}<0,05)$ tertinggi. Nisbah $\mathrm{C} 2 / \mathrm{C} 3$ mengikuti produksi C3 dan berbanding terbalik, ketika produksi C3 tertinggi maka nisbah C2/C3 terendah dan produksi gas metan yang dihasilkan pada P6 nyata $(\mathrm{P}<0,05)$ paling tinggi tapi tidak berbeda dengan P4 dan P5. Disimpulkan bahwa fermentabilitas rumput lapangan yang disuplementasi dengan 6 (enam) macam pakan suplemen sumber protein relatif sama, namun produksi gas metan yang rendah dihasilkan pada penambahan pakan suplemen dengan rasio urea dan molases $1: 5$ baik yang mengandung daun ketepeng maupun minyak ikan lemuru.
\end{abstract}

Kata kunci: rumput lapangan, suplemen, daun ketepeng, minyak ikan lemuru, gas metan.

\section{Comparison of Ketepeng Leaf Meal and Lemuru Fish Oil as a Methane Reduction Agent to Improve the Quality Ruminant Diet}

\begin{abstract}
The research was done to study the potential of ketepeng leaf meal and lemuru fish oil as agents to reduce methane production. The composition of feed supplements, lamtoro leave meal (LLM), urea (U) and mollases (M) were in different ratios: 1:5, 1:6 and 1:7 and ketepeng leaf meal (DKM) and lemuru fish oil (MIL). The feed supplement was added to the native grass as a basal diet, P1: $U: M=1: 5, D K M, P 2: U: M=1: 5, M I L, P 3: U: M=1: 6, D K M, P 4: U: M=1: 6, M I L$, P5: $U: M=1: 7, D K M, P 6: U: M=1: 7, M I L$. Research was done with in vitro gas technique. Inoculum was taken from rumen fluid of a fistulated male cow, which was taken before feeding in the morning. Rumen fluid $\mathrm{pH}$ did not significantly different, indicating the microbial fermentation in
\end{abstract}


rumen run well and normally were not affected by the treatment. The VFA production of P5 and P6 was significantly lower than $P 1, P 2, P 3$ and $P 4(P<0.05)$. Production of $C 2$ and $C 3$ were relatively the same except for $P 6(P<0.05)$ which relative higher. Ratio of $C 2 / C 3$ and inversely related $C 3$, when C3 production increased the C2/C3 ratio decreased $(P<0.05)$. Methane production of P6 was higher but did not different with P4 and P5. It can be concluded that diet which produced low methane was the native grass supplemented with urea and molases at ratio 1: 5 contained either ketepeng leaf meal or lemuru fish oil.

Key words: native grass, supplement, ketepeng leaf meal, lemuru fish oil, methane production.

\section{PENDAHULUAN}

Pada dasarnya ternak mengkonsumsi pakan untuk memenuhi kebutuhan energi. Energi ini dapat dipenuhi dari pakan ternak yang secara kuantiítas maupun kualitas sesuai dengan kebutuhan ternak. Disamping itu, interaksi antar nutrien sangatlah penting dalam kontribusinya memenuhi kebutuhan ternak. Hal ini akan tercermin dari efisiensi penggunaan pakan yang baik atau efisiensi penggunaan energi asal pakan yang tinggi bagi ternak. Banyak sekali faktor-faktor yang berpengaruh terhadap pemenuhan kebutuhan energi bagi ternak. Faktor tersebut antara lain palatabilitas, kandungan nutrien, kecernaan, rate of pasaje dan peran mikrobia dalam menjalankan fungsinya dalam proses fermentasi pakan di rumen.

Pakan yang masuk ke daalam rumen akan mengalami proses fermentasi oleh enzimenzim yang dihasilkan oleh mikrobia (McDonald et al., 1988). Produk akhir dari fermentasi karbohidrat daalam rumen adalah VFA (Volatile Fatty Acid) dengan komponen utamanya asam aasetat, propionat dan butirat. Sebagian besar VFA diabsorbsi oleh ternak sebagai sumber energi dan sebagian lain digunakan sebagai kerangka karbon dan bersama $\mathrm{NH}_{3}$ akan dimanfaatkan oleh mikrobia rumen untuk sintesis protein. Proses fermentasi pakan di dalam rumen juga menghasilkan produk samping berupa gas $\mathrm{CO}_{2}$ dan $\mathrm{CH}_{4}$, unyuk pembentukan produk samping yang berupa gas ini menyebabkan ternak kehilangan energi. Kehilangan energi dalam bentuk gas metan dan panas kurang lebih 6.5\% dari energi bruto (GE=Gross Energy), hal ini menunjukkan bahwa system biofermentasi anaerob dalam rumen tidak efisien. Produksi gas metan akan minimal jika kadar asam propionat dalam rumen tinggi (Sutardi, 1978). Selain kehilangan energi, emisi gas metan akan menyebabkan polusi lingkungan atau global warming (Anonim, 2004). Upaya penurunan atau penekanan produksi gas metan ini dapat dilakukan dengan penambahan senyawa quinon, asam fumarat, akrilat, 2-oksoglutarat, nitrat dan asam lemak tak jenuh.

Salah satu sumber asam lemak tak jenuh yang cukup efisien digunakan adalah minyak ikan lemuru yang merupakan limbah pengalengan ikan. Penggunaan minyak ikan lemuru ini memungkinkan terjadinya proses penjenuhan asam lemak tak jenuh dalam minyak ikan lemuru oleh hidrogen yang tersedia dalam rumen, yang seharusnya digunakan untuk pembentukan gas metan, sehingga dapat dikatakan bahwa asam lemak tak jenuh digunakan sebagai penangkap hydrogen (hydrogen sinks). Sedangkan daun ketepeng digunakan sebagai sumber quinon yang telah teruji menekan produksi gas metan.

Penelitian ini berupaya untuk menekan produksi gas metan menggunakan sumber kuinon dan asam lemak tak jenuh sebagai senyawa penangkap $\mathrm{H}_{2}$ (hydrogen synk) dalam rumen. Keberhasilan upaya ini akan dicerminkan dari optimalisasi biofermentasi mikrobia dalam rumen.

\section{MATERI DAN METODE}

Penelitian dilakukan di Laboratorium Ilmu Nutrisi dan Makanan Ternak, Fakultas Pertanian UNS dan Laboratorium Biokimia 
Nutrisi, Fakultas Peternakan UGM selama 3 bulan.

Penelitian ini dikerjakan dengan menggunakan teknik in vitro yang telah dikembangkan oleh Steingas dan Menke (Ørskov, 2002, Schofield, 2000; Schofield et al., 1994). Sebagai sumber inokulum berasal dari sapi berfistula rumen yang diberikan ransum standar dengan kadar protein $12 \%$ dan TDN 70\%. Pengambilan cairan rumen dengan menggunakan stomach tube pada saat sebelum distribusi ransum pada pagi hari. Setelah diambil dimasukkan kedalam termos panas yang telah diatur sekitar $39-40^{\circ} \mathrm{C}$. Selanjutnya sebelum digunakan untuk proses fermentasi ransom perlakuan, cairan rumen disaring dengan kain kasa untuk menyaring pakan yang belum terfermentasi. Setelah itu, cairan rumen siap untuk digunakan sebagai sumber inokulum pada pengukuran parameter metabolik dengan teknik in vitro.

Perlakuan yang diterapkan sebanyak 6 (enam) perlakuan yaitu 6 macam suplemen dengan komposisi yang berbeda pada ransum basal rumput lapangan (100\%). Komposisi suplemen tersebut pakan sumber protein yang digunakan yaitu tepung daun lamtoro sebagai penyedia protein yang soluble dan tahan degradasi (bypass protein). Perbandingan urea dan molases sebesar $1: 5,1: 6$ dan $1: 7$, urea dan molases dengan perbandingan yang berbeda bertujuan untuk mengetahui pada rasio berapa urea dan molasses mampu menyediakan Nitrogen dan energi tersedia untuk sintesis $\mathrm{N}$ mikrobia rumen. Selain itu digunakan daun ketepeng dan minyak ikan lemuru, masingmasing mengandung kuinon dan asam lemak tak jenuh (PUFA, Poly Unsaturated Fatty Acid) sebagai agensia reduksi metan dalam upaya menurunkan energi yang hilang melalui pembentukan gas metan.

Suplemen ini ditambahkan dengan jumlah pemberian sesuai dengan rekomendasi de Young dan Bruchem (1999), susunan perlakuannya adalah :

1. DK- U:M = 1:5 yaitu, daun ketepeng, rasio urea : molases $=1: 5$

2. MIL- U:M = 1:5 yaitu minyak ikan lemuru, rasio urea : molases $=1: 5$

3. DK- U:M = 1:6 yaitu daun ketepeng, rasio urea $:$ molases $=1: 6$

4. MIL- U:M = 1:6 yaitu, minyak ikan lemuru rasio urea : molases $=1: 6$

5. DK- U:M = 1:7 yaitu, daun ketepeng rasio urea $:$ molases $=1: 7$

6. MIL- U:M = 1:7 yaitu, minyak ikan lemuru rasio urea : molases $=1: 7$

Kandungan nutrien suplemen dan rumput lapangan yang akan dikaji dalam penelitian ini tersaji pada tabel berikut. Analisis pada bahan percobaan ini menggunakan metode analisis proksimat (AOAC, 1980).

Gas test merupakan salah satu metode in vitro guna penentuan kualitas suatu bahan pakan ternak yang dikembangkan oleh Menke (Orskov, 2002; Schofield, 2000; Schofield et al., 1994). Produksi gas ini menggambarkan efisiensi biofermentasi dalam rumen (Sutardi, 1978). Manfaat pengukuran dengan teknik ini memberikan gambaran estimasi laju digesti

Tabel 1. Kandungan nutrien suplemen dan rumput lapangan $\left(\right.$ dalam BK) ${ }^{*}$

\begin{tabular}{lccccc}
\hline \hline \multicolumn{1}{c}{ Perlakuan } & PK (\%) & LK (\%) & SK (\%) & Abu (\%) & TDN (\%) $\left.{ }^{* *}\right)$ \\
\hline DK-UM=1:5 & 33,23 & 5,92 & 12,35 & 13,99 & 70,11 \\
MIL-UM=1:5 & 33,27 & 6,91 & 8,25 & 11,49 & 75,82 \\
DK-UM=1:6 & 33,82 & 5,39 & 8,07 & 14,53 & 75,16 \\
MIL-UM=1:6 & 32,29 & 6,55 & 7,15 & 14,58 & 75,89 \\
DK-UM=1:7 & 34,78 & 4,39 & 6,05 & 13,66 & 75,53 \\
MIL-UM=1:7 & 33,32 & 5,21 & 8,23 & 12,39 & 74,04 \\
RL & 12,26 & 2,22 & 16,58 & 11,92 & 61,34 \\
\hline
\end{tabular}

*) Hasil analisis Laboratorium Ilmu Nutrisi dan Makanan Ternak

**) Estimat TDN $=59.68-1.08 \mathrm{SK}+0.3136 \mathrm{PK}+1.22 \mathrm{~L}+0.2508$ BETN (Sutardi, 1991).

RL : Rumput Lapangan 
pakan yang ada hubungannya dengan produksi VFA (Blümmel dan Orskov, 1993) dan dapat digunakan untuk mengukur degradasi pakan dalam rumen dan sebagai indicator intake bahan kering tercerna serta kecepatan pertumbuhan ternak (Liu et al, 2001). Selanjutnya dilaporkan bahwa adanya efek asosiasi antar pakan atau suplementasinya, karena perbedaan kandungan nutrien dalam setiap pakan atau kombinasinya juga akan menghasilkan perbedaan gas yang terbentuk.

Sumber inokulum pada percobaan ini diambil cairan rumen dari sapi berfistula rumen. Cairan rumen yang telah diambil, disaring dengan kain kasa rangkap 4 dan dimasukkan kedalam termos panas yang sebelumnya diisi dengan air bersuhu $39^{\circ} \mathrm{C}$. Pengambilan cairan rumen dilakukan pada saat sebelum sapi diberi makan pagi.

Preparasi sampel. Substrat yang akan dievaluasi digiling dengan Hammer mill berukuran $1 \mathrm{~mm}$ sebanyak 200 mg, dimasukkan kedalam glass syringe atau piston pipette dan dicatat jumlah yang sesungguhnya. Selanjutnya piston pipette diolesi dengan vaselin putih dan diinkubasikan pada suhu $38^{\circ} \mathrm{C}$ dalam inkubator.

Perhitungan data. Pada berat sampel $200 \mathrm{mg}$ (as fed basis) akan diperoleh produksi gas pada setiap jam inkubasi sebesar :

\section{$\mathrm{V}_{\text {200mg BK }}=\frac{\text { Volume gas }}{- \text { \% BK }^{-}}$}

Misalnya pada inkubasi 72 jam, maka :

$V_{72}=\left(V_{72}-V_{0}\right)-\left(V B_{72}-V B_{0}\right) \times F K_{\text {(standart })}$

Dimana :

$\mathrm{V}_{16}$ : skala volume syringe sampel pada inkubasi 72jam

$\mathrm{V}_{\mathrm{O}} \quad$ : skala volume syringe sampel pada inkubasi 0 jam

$\mathrm{VB}_{16}$ : skala volume syringe blanko pada inkubasi 72 jam

$\mathrm{VB}_{\mathrm{O}}$ : skala volume syringe blanko pada inkubasi 0 jam

$\mathrm{FK}_{\text {(standart): faktor koreksi dari sampel standart }}$
Analisis gas metan dilakukan dengan teknik kromatografi gas, menggunakan alat Gas Chromatography, merk Hitachi, model 263-50. Detektor : FID, kolom carbon aktif, panjang 1 $\mathrm{m}$ dengan diameter $3 \mathrm{~mm}$. Temperatur injektor $190^{\circ} \mathrm{C}$, detector $190^{\circ} \mathrm{C}$ dan kolom $170^{\circ} \mathrm{C}$. Laju aliran gas $\mathrm{N}_{2} 50 \mathrm{ml} /$ menit; $\mathrm{H}_{2} 1 \mathrm{~kg} / \mathrm{cm}^{2}$ dan udara $1 \mathrm{~kg} / \mathrm{cm}^{2}$

Produksi Asam Lemak Atsiri (Volatile Fatty Acids = VFA). Pengukuran produksi VFA bertujuan untuk mengetahui potensi ransum percobaan ditinjau dari fermentabilitasnya maupun kemampuannya dalam menyediakan energi bagi mikroba rumen dan induk semangnya.

Preparasi sampel. Cairan rumen hasil fermentasi ransum percobaan yang telah diinkubasikan selama 48 jam disentrifugasi dengan kecepatan 3000 rpm selama 10 menit sebanyak $0.2 \mathrm{ml}$ ditambahkan asam metafosfat $1 \mathrm{ml}$ diinjeksikan pada Gas Kromatografi merk Shimadzu, model GC8, suhu kolom 130oC, suhu injector atau detector 220oC. Gas pembawa N2 dengan laju atau tekanan 1.25 $\mathrm{kg} / \mathrm{cm} 2$. Kolom yang digunakan SP-1200/1\% $\mathrm{H}_{3} \mathrm{PO} 4, \quad 80 / 100$ mesh chromosorb WAW. GP10\% SP, panjang kolom $2 \mathrm{~m}$, diameter 3 mm. Dtektor FID, volume injeksi 0.5 ul. Alat ini dilengkapi dengan Integrator Shimadzu GR3A.

\section{HASIL DAN PEMBAHASAN}

Hasil pengukuran, $\mathrm{pH}$ cairan rumen produksi VFA total dan parcial yaitu produksi asam asetat $\left(\mathrm{C}_{2}\right)$ dan asam propionat $\left(\mathrm{C}_{3}\right)$, konsentrasi $\mathrm{NH}_{3}$, produksi gas metan dan produksi gas total tertera pada tabel di bawah ini.

Kondisi lingkungan dalam rumen harus selalu terjaga mengingat didalam rumen terdapat mikrobia terutama bakteri dan protozoa yang sangat besar peranannya dalam proses pencernaan fermentatif. Kehidupan mikrobia ini menuntut suatu keadaan yang serasi sesuai dengan yang dibutuhkan untuk dapat didup dan berkembang yang optimal.

Derajat keasaman (pH) rumen 
Tabel 2. Respon perbedaan agensi reduksi metan terhadap fermentabilitas ransum dan produksi gas dalam rumen.

\begin{tabular}{ccccccc}
\hline \hline \multirow{2}{*}{ Peubah } & \multicolumn{2}{c}{$\mathbf{U}: \mathbf{M}=\mathbf{1}: \mathbf{5}$} & \multicolumn{2}{c}{$\mathbf{U}: \mathbf{M}=\mathbf{1}: \mathbf{6}$} & \multicolumn{2}{c}{$\mathbf{U}: \mathbf{M}=\mathbf{1}: \mathbf{7}$} \\
\cline { 2 - 7 } & $\mathbf{D K}$ & $\mathbf{M I L}$ & $\mathbf{D K}$ & $\mathbf{M I L}$ & $\mathbf{D K}$ & $\mathbf{M I L}$ \\
& $\boldsymbol{P 1}$ & $\boldsymbol{P} \mathbf{2}$ & $\boldsymbol{P 3}$ & $\boldsymbol{P 4}$ & $\boldsymbol{P 5}$ & $\boldsymbol{P} 6$ \\
\cline { 2 - 7 } $\mathrm{pH}$ & $6,83^{\mathrm{a}}$ & $6,81^{\mathrm{a}}$ & $6,78^{\mathrm{a}}$ & $6,80^{\mathrm{a}}$ & $6,82^{\mathrm{a}}$ & $6,81^{\mathrm{a}}$ \\
Prod. VFA total & $97,10^{\mathrm{ab}}$ & $98,85^{\mathrm{ab}}$ & $93,02^{\mathrm{ab}}$ & $102,66^{\mathrm{a}}$ & $82,74^{\mathrm{b}}$ & $84,68^{\mathrm{b}}$ \\
$\bullet \mathrm{C}_{2}$ & $65,68^{\mathrm{ab}}$ & $71,17^{\mathrm{a}}$ & $63,70^{\mathrm{ab}}$ & $66,34^{\mathrm{ab}}$ & $54,22^{\mathrm{c}}$ & $57,84^{\mathrm{bc}}$ \\
$\bullet \mathrm{C}_{3}$ & $21,90^{\mathrm{ab}}$ & $21,68^{\mathrm{b}}$ & $20,42^{\mathrm{b}}$ & $26,62^{\mathrm{a}}$ & $20,60^{\mathrm{b}}$ & $19,42^{\mathrm{b}}$ \\
$\bullet$ Nisbah $\mathrm{C}_{2} / \mathrm{C}_{3}$ & $3,00^{\mathrm{ab}}$ & $3,30^{\mathrm{a}}$ & $3,12^{\mathrm{a}}$ & $2,51^{\mathrm{c}}$ & $2,64^{\mathrm{bc}}$ & $3,04^{\mathrm{ab}}$ \\
Prod. gas metan & $13,15^{\mathrm{c}}$ & $13,38^{\mathrm{bc}}$ & $12,09^{\mathrm{c}}$ & $15,79^{\mathrm{a}}$ & $15,20^{\mathrm{ab}}$ & $15,09^{\mathrm{ab}}$ \\
\hline
\end{tabular}

abc Superskrip yang berbeda pada baris yang sama menunjukkan perbedaan yang nyata $(\mathrm{P}<0,05)$

U:urea, M:molases, DK:daun ketepeng, MIL:minyak ikan lemuru

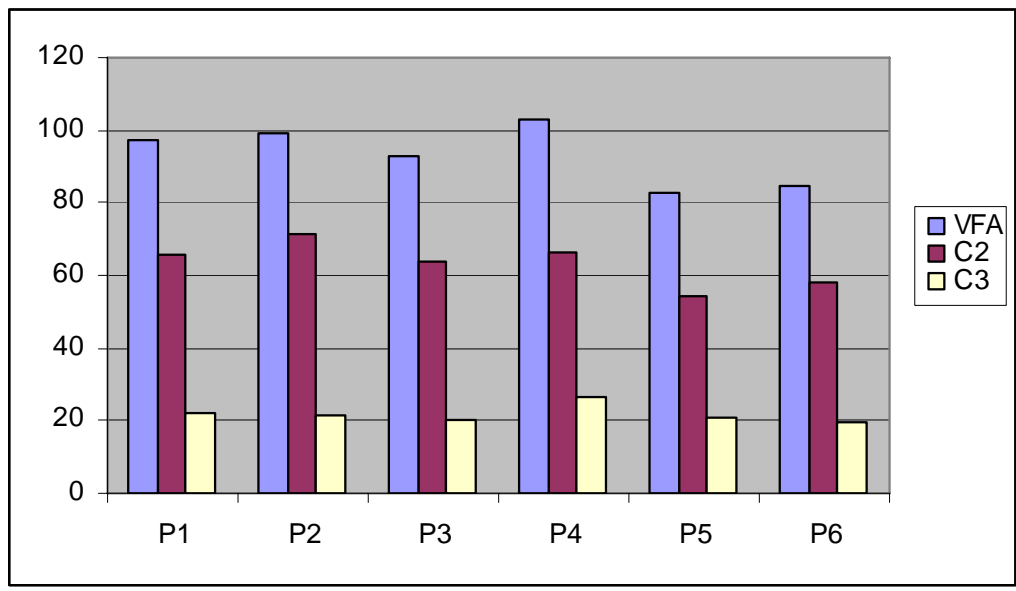

Gambar 1. Pengaruh perlakuan terhadap produksi VFA, asam asetat dan asam propionat

merupakan salah satu kondisi rumen yang selalu berada pada kondisi yang normal sehingga mikrobia dapat tumbuh dan berkembang secara baik serta dapat menjalankan aktivitasnya dengan baik pula. Pada penelitian ini terlihat bahwa $\mathrm{pH}$ yang dihasilkan berkisar pada $\mathrm{pH}$ yang normal. Pencernaan mikrobia selulolitik dalam mencerna selulosa, menghendaki $\mathrm{pH}$ berkisar antara 6.2 - 6.8. Hal ini dapat dijelaskan bahwa suplementasi yang dilakukan pada ransum basal rumput lapangan tidak mengakibatkan adanya perubahan kondisi lingkungan rumen yang dapat mengganggu normalitas kehidupan mikrobia dan peranannya.

Produksi VFA merupakan hasil akhir dari proses fermentasi karbohidrat baik struktural maupun non struktural oleh mikroorganisme dalam rumen. Hasil akhir yang utama adalah asam asetat $\left(\mathrm{C}_{2}\right)$, asam propionat $\left(\mathrm{C}_{3}\right)$ dan asam butirat $\left(\mathrm{C}_{4}\right)$. VFA ini juga diproduksi oleh fermentasi mikrobial dari protein pakan, selain asam amino dan amonia.

VFA yang dihasilkan oleh ransum percobaan memberikan hasil yang cukup baik dan dapat dijelaskan VFA berada pada kondisi yang normal yang berkisar antara 82.74 $102.66 \mathrm{mM}$. Keadaan ini secara umum menunjukkan rumput lapangan yang disuplementasi mempunyai kualitas yang baik ditinjau dari tingkat fermentabilitasnya.

Tinggi rendahnya produksi VFA mencerminkan fermentabilitas ransum, selanjutnya fermentabilitas ransum tergantung dari komponen karbohidrat yang menyusunnya. Berdasarkan hal tersebut, maka fermentabilitas ransum pada rasio $\mathrm{U}: \mathrm{M}$ yang sama yaitu $1: 5$, produksi VFAnya berbeda tidak nyata baik 
penambahan dengan agensi reduksi metan asal daun ketepeng (DK) maupun minyak ikan lemuru (MIL), demikian pula untuk rasio $\mathrm{U}: \mathrm{M}$ - 1 : 6 dan 1 : 7. Namun jika dibandingkan antar rasio urea dan molases, maka produksi VFA terendah $(\mathrm{P}<0.05)$ dihasilkan oleh rasio $\mathrm{U}$ $: \mathrm{M}=1: 7$. Dapat dikatakan nyata $(\mathrm{P}<0.05)$ lebih rendah dibandingkan rasio $\mathrm{U}: \mathrm{M}$ yang lainnya (1: 5 dan $1: 6)$. Hal ini menunjukkan bahwa sintesis mikrobia yang berperan dalam proses fermentatif dalam rumen tergantung dari keserasian dan interaksi antar nutrien dalam ransum sehingga banyak sekali faktor yang berpengaruh terhadap fermentabilitas ransum.

Berdasarkan Tabel 2 dan penjelasan di atas, maka tinggi rendahnya produksi VFA lebih dipengaruhi oleh perbedaan rasio urea dan molases, 1 : 5, 1: 6 dan 1 : 7 dari pada perbedaan daun ketepeng dan minyak ikan lemuru sebagai sumber kuinon dan PUFA (Poly Unsaturated Fatty Acid).

Ditinjau dari produksi $\mathrm{C}_{3}$ dan $\mathrm{C}_{2}$ dan nisbah $\mathrm{C}_{2} / \mathrm{C}_{3}$, terlihat bahwa nisbah terendah $(\mathrm{P}<0.05)$ adalah P4 (U:M=1:6, MIL) yaitu sebesar 2.51, ini menunjukkan tingginya produksi $\mathrm{C}_{3}$ dan rendahnya produksi $\mathrm{C}_{2}$. Produksi asam asetat $\left(\mathrm{C}_{2}\right)$ dan asam propionat $\left(\mathrm{C}_{3}\right)$ mengikuti tingkat produksi VFA. Pada masing-masing rasio urea dan molases, antara daun ketepeng dan minyak ikan lemuru tidak menunjukkan adanya perbedaan yang nyata. Namun pada rasio urea : molases sebesar $1: 6$, ternyata ada perbedaan yang nyata $(\mathrm{P}<0.05)$ antara daun ketepeng dan minyak ikan lemuru terhadap nisbah $\mathrm{C}_{2} / \mathrm{C}_{3}$. Produksi gas merupakan hasil samping dari proses fermentatif mikrobial dari bahan organik ransum. Semakin banyak bahan organik yang terkandung dalam ransum dan tercerna di rumen, maka produksi gas juga akan semakin tinggi. Produksi gas ini merupakan indikator tingkat degradabilitas ransum. Selain itu produksi gas juga merupakan indikator efisiensi energi ransum, tingginya gas yang terbentuk mengakibatkan tingginya energi yang terbuang dalam bentuk gas. Gas metan terbentuk dari gas $\mathrm{CO}_{2}$ dan gas $\mathrm{H}_{2}$ yang terbentuk selama proses fermentasi berlangsung. Peningkatan produksi asam propionat (C3) dapat menurunkan produksi gas metan karena pembentukan asam propinat lebih banyak membutuhkan $\mathrm{H}_{2}$, sedangkan asam asetat dan butirat menghasilkan $\mathrm{H}_{2}$. Hasil ini berbeda dengan hasil yang diperoleh Erwanto (1995) bahwa penurunan produksi gas metan señalan dengan peningkatan produksi asam propionat. Hasil penelitian ini terlihat tidak konsisten antara produksi asam propionat dengan produksi gas metan, keadaan ini lebih disebabkab karena adanya efek asosiasi antar nutrien dalam ransum. Produksi gas metan yang rendah dihasilkan oleh rumput lapangan yang disuplementasi dengan pakan suplemen sumber protein dengan rasio urea dan molases $1: 5$ baik yang mengandung daun ketepeng maupun minyak ikan lemuru sebagai agensia reduksi metan.

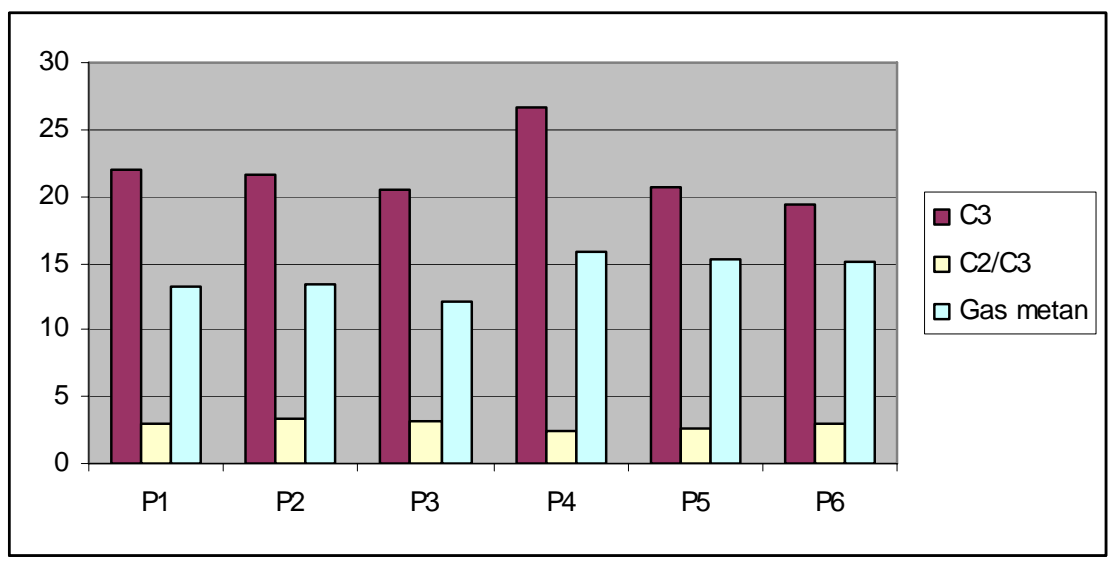

Gambar 2. Pengaruh perlakuan terhadap produksi asam propionat, gas metan dan nisbah $\mathrm{C}_{2} / \mathrm{C}_{3}$ 


\section{KESIMPULAN}

Fermentabilitas rumput lapangan yang disuplementasi dengan 6 (enam) macam pakan suplemen sumber protein relatif sama, namun produksi gas metan yang rendah dihasilkan pada penambahan pakan suplemen dengan rasio urea dan molases 1 : 5 baik yang mengandung daun ketepeng maupun minyak ikan lemuru.

\section{UCAPAN TERIMA KASIH}

Penulis mengucapkan terima kasih kepada pemberi dana pada penelitian ini yaitu DP2M. Ucapan terima kasih juga disampaikan kepada Ketua Laboratorium Biokimia Nutrisi dan Ketua Laboratorium Teknologi Pakan Fakultas Peternakan UGM yang telah memberikan fasilitas laboratorium dan analisis bahan percobaan.

\section{DAFTAR PUSTAKA}

Association of Official Analysis Chemist. 1980. Official methods of analysis of the Association of Official Analytical Chemist. 13th ed. Association of Official Analytical Chemist, Washington, DC.

Beuvink, J.M.W., and J. Kogut. Modeling gas production kinetics of grass silages incubated with buffered ruminal fluid. J. Anim. Sci. 71 : 1041 - 1046.

Blümmel, M., and E.R. Ørskov. 1993. Comparison of in vitro gas production and nylon bag degradability of roughages in predicting feed intake in cattle. Animal Feed Scinece ant Technology, 40 : 109 - 119.

Doane, P.H., P. Schofield, and A.N. Pell. 1997. Neutral detergent fiber disappearance and gas and volatile fatty acid production during the in vitro fermentation of six forages. J. Anim. Sci. $75: 3342-3352$.

Erwanto. 1995. Optimalisasi System Fermentasi Rumen Melalui Suplementasi Sulfur,
Defaunasi, Reduksi Emisi Metan Dan Stimulasi Pertumbuhan Mikroba Pada Ternak Ruminansia. Disertasi. Program Pascasarjana, IPB Bogor.

Liu, J.X., A.Susenbeth, and K.H. Südekum. 2002. In vitro gas production measurements to evaluate interaction between untreated and chemically treated rice straw, grass hay, and mulberry leaves. J. Anim. Sci. 80 : 517 - 524.

McDonald, P., R.A. Edward and J.F.D. Greenhalgh. 1988. Animal Nutrition. $4^{\text {th }}$ edition. English Language Book Society, Longman, London.

Schofield, P., R.E. Pitt, and A.N. Pell. 1994. Kinetics of fiber digestion from in vitro gas production. J. Anim. Sci. 72 : 2980 - 2991.

Schofield, P. 2000. Gas Production Methods. In: Farm Animal Metabolism and Nutrition. Edited by J.P.F. D’Mello. CABI Publishing, New York, USA.

Sunarso. 1984. Mutu Protein Limbah Agro_Industri Ditinjau dari Kinetika Perombakannya oleh Mikroba Rumen dan Potensinya dalam Menyediakan Protein Bagi Pencernaan Pasca Rumen. Thesis. Program Pasca Sarjana, IPB. Bogor.

Sutardi, T. 1978. Ikhtisar Ruminologi. Dept. Ilmu Makanan Ternak, Fakultas Peternakan IPB. Bogor.

Sutardi, T. 1993. Peningkatan Produksi Ternak Ruminansia melalui Amoniasi Pakan Bermutu Rendah, Defaunasi dan Suplementasi Sumber Protein Tahan Degradasi Rumen. Laporan Penelitian Hibah Bersaing I/1. Fakultas Peternakan IPB. Bogor.

Widyobroto BP., SPS. Budhi, A. Agus and B. Santosa. 1999. Effect of undegraded protein level on nutrient digestibility and microbial protein synthesis of dairy cows. In : Lobley GE, A. White and JC. MacRae. (Ed). Protein metabolism and nutrition. Book of abstracts of the VIIIth International Symposium on Protein and Metabolism. P. 72. EAAP publication Wageningen Holland. 